\title{
EFFECT OF IRRIGATION FREQUENCY UNDER HAND MOVE LATERAL AND SOLID SET SPRINKLER IRRIGATION ON WATER USE EFFICIENCY AND YIELD OF WHEAT
}

\author{
A. R. Eid*; M. E. Abuarab ${ }^{* *}$
}

\section{ABSTRACT}

The water-use characteristics of wheat were studied in the field under sprinkler irrigation system. Treatments consisted of two sprinkler irrigation systems, solid set sprinklers $\left(S_{1}\right)$ and hand move laterals $\left(S_{2}\right)$, and three irrigation frequencies (IF 1 : once per week; IF $F_{2}$ twice per week, IF $:$ three times per week). Total irrigation amount values varied from 4558.160 to $5094.992 \mathrm{~m}^{3} . \mathrm{ha}^{-1}$ in 2009-2010 and 4792.457 to $5471.243 \mathrm{~m}^{3} . \mathrm{ha}^{-1}$ in 2010-2011. The highest seasonal ET was obtained from the $S_{2} I F_{3}$ treatment in 2010-2011 (5417.073 $\left.\mathrm{m}^{3} . h \mathrm{a}^{-1}\right)$; the lowest value was observed in the $S_{1} I F_{1}$ treatment in 2009-2010 $4513.029 \mathrm{~m}^{3} . \mathrm{ha}^{-}$ $\left.{ }^{1}\right)$. On average, the $S_{1} I F_{3}$ treatment gave the highest grain yield (6000 kg.ha ${ }^{-1}$ ), whereas $S_{2} I F_{1}$ treatment gave the lowest grain yield (3332.500 $\mathrm{kg} . \mathrm{ha}^{-1}$ ). The highest irrigation water use efficiency (IWUE) values were obtained from $S_{1} I F_{3} 1.179 \mathrm{~kg} \cdot \mathrm{m}^{-3}$ and $1.151 \mathrm{~kg} . \mathrm{m}^{-3}$ in 2009-2010 and 2010-2011, respectively, while the lowest values were obtained from $S_{2} I F_{1} 0.710 \mathrm{~kg} \cdot \mathrm{m}^{-3}$ and $0.699 \mathrm{~kg} \cdot \mathrm{m}^{-3}$ in 2009-2010 and 2010-2011, respectively. The highest water use efficiency (WUE) values were obtained from $S_{1} I F_{3} 1.191 \mathrm{~kg} \cdot \mathrm{m}^{-3}$ and $1.163 \mathrm{~kg} \cdot \mathrm{m}^{-3}$ in 2009-2010 and 2010-2011, respectively, while the lowest values were obtained from $S_{2} I_{1} 0.717 \mathrm{~kg} \cdot \mathrm{m}^{-3}$ and $0.706 \mathrm{~kg} \cdot \mathrm{m}^{-3}$ in 2009-2010 and 2010-2011, respectively. The highest nitrogen use efficiency (NUE), phosphor use efficiency (PUE) and potassium use efficiency (KUE) were obtained under $S_{1} I F_{3}$ and the lowest value was obtained under $S_{2} I F_{1}$. Soil water content varied apparently in the 0-40-cm soil layer. For winter wheat in the El-Nubaria, the recommended sprinkler system and irrigation frequency for each event is solid set sprinkler $\left(S_{1}\right)$ and irrigation three times per week $\left(I_{3}\right)$.

Key words: Irrigation frequency, solid set sprinkler, hand move laterals, wheat, IWUE, WUE, soil moisture content.

* Assistant Professor, Water relations and field irrigation department, NRC, Giza, Egypt ** Assistant Professor of Irrigation and Drainage Eng.- Faculty of Agric.- Cairo Univ. 


\section{INTRODUCTION}

Trigated agriculture produces about $40 \%$ of all food, and consumes $69 \%$ of all freshwater resources (FAO, 2000). Global population growth is expected to increase the demand for cereals including rice and wheat by $1.27 \%$ annually between 2000 and 2025 (Rosegrant and Cai, 2000). To meet the projected demand for food, irrigated agriculture will require an increase of $17 \%$ in freshwater resources (Seregeldin, 1999).

In many arid and semi-arid countries where population growth is high, and freshwater is in short supply, there is pressure on the agricultural sector to reduce its water consumption and make it available for the urban and industrial sectors. This drives the demand to produce cereals, especially rice and wheat, using lower amount of irrigation water.

Wheat is one of the most important crops in the world. Well-drained clay loam, loam, and sandy loam soils are particularly suitable for this crop. Therefore, proper management of inputs particularly irrigation water using modern technology is essential for maximizing production and for providing high returns to farmers. Provided the area of cropped land does not increase, increasing water use efficiency is one of the most important ways to increase crop production, save water and protect the environment (Haijun Liu et al., 2011). Wheat is quite sensitive to water stress. Therefore, it needs frequent irrigation for good growth and yield (Mishra et al., 1995; Alderfasi and Nielsen, 2001).

Irrigation frequency refers to the number of days between irrigation during periods without rainfall. It depends on consumptive use of rate of a crop and on the amount of available moisture in the crop root zone. It is function of crop, soil and climate. Sandy soils must be irrigated more often than fine texture deep soils. A moisture use ratio varies with the kind of crop and climate conditions and increases as crop grows larges and days become longer and hotter.

Irrigation frequency is one of the most important factors in pressurized irrigation scheduling. Due to the differences in soil moisture and wetting pattern, crop yields may be different when the same quantity of water is applied under different irrigation frequencies. Typically, the higher the irrigation frequency the smaller the wetted soil volume and the higher 
mean soil water content can be maintained in the wetted soil volume during a period when the total irrigation water is equal. High irrigation frequency might provide desirable conditions for water movement in soil and for uptake by roots (Segal et al., 2000). Several experiments have shown positive responses in some crops to high frequency drip irrigation (Freeman et al., 1976; Segal et al., 2000; Sharmasarkar et al., 2001). However, seeming inconsistencies as to what frequency might be optimum can also be found in the literature. Dalvi et al. (1999), found that the maximum yield was obtained at every second day frequency. The irrigation frequency had significant effect on yields of field grown green bean under the Mediterranean climatic conditions in Egypt. The number of frequencies per each irrigation had significant effect on yield and nutrients concentration in the soil. The results indicated that WUE and IWUE values decreased with decreasing irrigation frequencies. It was found that the highest concentration of all determined nutrient elements was obtained in the high irrigation frequency. While, the lowest concentration was obtained in the low irrigation frequency (Abuarab et al., 2011).

A study on irrigation frequency in potato showed that irrigation frequency did affect soil water distribution under potato depending on potato growing stage, soil depth and distance from the emitter. Potato root growth was also affected by drip irrigation frequency to some extent: the higher the frequency, the higher was the root length density in 0-60 $\mathrm{cm}$ soil layer and the lower was the root length density in $0-10 \mathrm{~cm}$ soil layer. On the other hand, potato roots were not limited in wetted soil volume even when the crop was irrigated at the highest frequency. High frequency irrigation enhanced potato tuber growth and water use efficiency (WUE). Reducing irrigation frequency resulted in significant yield reductions by 33.4 and $29.1 \%$ (Wang et al., 2006).

Sprinkler irrigation is an advanced irrigation technique for water-saving and fertigation and in accurately controlling irrigation time and water amount (Li and Rao, 2003). Study on winter wheat showed that crop yield and water use efficiency in sprinkler-irrigated fields was higher than that in surface irrigated fields (Yang et al., 2000). The result of high crop yield and water use efficiency in sprinkler-irrigated field is partly 
because sprinkler irrigation can produce a favorable microclimate for crop growth. Tolk et al. (1995) found sprinkler irrigation resulted in crop transpiration reduction by more than $50 \%$ during irrigation process. The increasing in photosynthesis rate and reduction in leaf respiration rate at night also has been found in sprinkler-irrigated area (Chen, 1996; Yang et al., 2000).

The nutrient concentrations in the rhizosphere may be high or even excessive immediately after irrigation and may fall to deficit levels as time proceeds (Xu et al., 2004). Reducing the time interval between successive irrigations in order to maintain constant, optimal water content in the root zone may reduce the variations in nutrient concentration, thereby increasing their availability to plants (Silber et al., 2003).

The specific objectives of the study were (1) To study the effects of irrigation frequency on root zone soil water status, growth, yield parameters, and water use efficiency of wheat; (2) To recommend an effective irrigation water management strategy for wheat grown in arid regions, particularly under conditions of water limitation.

\section{MATERIALS AND METHODS}

\subsection{Site description}

Field experiments were conducted during two wheat seasons from December to May of 2009-2011 at the experimental farm of National Research Center, El-Nubaria, Egypt (latitude 30.8667N, and longitude 31.1667E, and mean altitude $21 \mathrm{~m}$ above sea level).

The experimental area has an arid climate with cool winters and hot dry summers prevailing in the experimental area. Table (1) summarizes the monthly mean climatic data for the two growing seasons 2010 and 2012, respectively, for El-Nubaria city, which are nearly the same. The data of maximum and minimum temperature, relative humidity, and wind speed were obtained from "The Central Laboratory of Meteorology" which is related to The Ministry of Agriculture. There was not rainfall that could be taken into consideration through the two seasons, because the amount was very little and the duration didn't exceed few minutes. 


\subsection{Soil physical and chemical properties}

The soil of experimental site is classified as sandy soil. Some of the physical and chemical properties of the experimental soil are displayed in Table 2 and Table 3 respectively. Irrigation water was obtained from an irrigation channel going through the experimental area, with $\mathrm{pH} 7.35$, and an average electrical conductivity of $0.41 \mathrm{dS} \mathrm{m}^{-1}$.

Table 1. Monthly and growing season climatic data of the experimental site

\begin{tabular}{|c|c|c|c|c|c|c|c|c|c|}
\hline \multirow[t]{2}{*}{ Month } & \multirow{2}{*}{$\begin{array}{c}\text { Growing } \\
\text { season }\end{array}$} & \multirow{2}{*}{$\begin{array}{c}\text { Solar } \\
\text { radiation } \\
\left(\mathbf{W} / \mathbf{m}^{2}\right)\end{array}$} & \multirow{2}{*}{$\begin{array}{l}\text { Precipitation } \\
\quad(\mathbf{m m})\end{array}$} & \multicolumn{2}{|c|}{$\begin{array}{l}\text { Wind speed } \\
(\mathrm{m} / \mathrm{sec})\end{array}$} & \multicolumn{3}{|c|}{ Air temp $\left({ }^{\circ} \mathrm{C}\right)$} & \multirow{2}{*}{$\begin{array}{c}\text { Relative } \\
\text { Humidity } \\
(\%)\end{array}$} \\
\hline & & & & Aver. & Max. & Aver. & Min. & Max. & \\
\hline December & 2009- & 49.4 & 0.2 & 1.8 & 4.7 & 15.6 & 8.9 & 22.2 & 63.3 \\
\hline January & & 49.7 & 0.0 & 2.3 & 6.0 & 14.7 & 8.3 & 21.4 & 61.0 \\
\hline February & & 67.5 & 0.1 & 2.1 & 5.8 & 16.7 & 9.3 & 24.5 & 57.7 \\
\hline March & & 93.5 & 18.6 & 2.2 & 5.5 & 18.3 & 11.0 & 26.2 & 60.0 \\
\hline April & & 111.0 & 0.0 & 2.3 & 7.6 & 20.8 & 12.8 & 28.8 & 52.3 \\
\hline May & & 130.0 & 0.0 & 1.4 & 4.2 & 20.6 & 12.7 & 27.6 & 49.0 \\
\hline December & 2010- & 49.5 & 0.0 & 2.0 & 4.8 & 19.74 & 9.10 & 22.55 & 63.4 \\
\hline January & & 50.0 & 1.2 & 2.5 & 6.2 & 15.25 & 7.31 & 24.13 & 66.0 \\
\hline February & & 68.0 & 2.6 & 2.3 & 6.0 & 16.4 & 7.17 & 26.39 & 56.0 \\
\hline March & & 95.0 & 0.0 & 2.5 & 5.8 & 17.61 & 8.19 & 28.26 & 56.0 \\
\hline April & & 113.0 & 0.0 & 2.4 & 7.8 & 21.23 & 10.87 & 30.55 & 50.0 \\
\hline May & & 135.0 & 0.0 & 1.6 & 4.5 & 24.83 & 14.29 & 33.8 & 47.0 \\
\hline
\end{tabular}

Table 2. Soil physical characteristics of experimental site

\begin{tabular}{|c|c|c|c|c|c|c|c|}
\hline \multirow{2}{*}{$\begin{array}{c}\text { Soil } \\
\text { depth } \\
\text { (cm) }\end{array}$} & \multicolumn{3}{|c|}{ Particle size distribution } & \multirow{2}{*}{$\begin{array}{l}\text { Texture } \\
\text { class }\end{array}$} & \multirow{2}{*}{$\begin{array}{l}\text { SP. } \\
(\%)\end{array}$} & \multirow[b]{2}{*}{$\begin{array}{l}\text { F.C. } \\
(\%)\end{array}$} & \multirow{2}{*}{$\begin{array}{l}\text { W.P. } \\
(\%)\end{array}$} \\
\hline & $\begin{array}{l}\text { Coarse } \\
\text { Sand }\end{array}$ & $\begin{array}{l}\text { Fine } \\
\text { sand }\end{array}$ & $\begin{array}{l}\text { Clay } \\
+ \text { Silt }\end{array}$ & & & & \\
\hline $0-20$ & 47.76 & 49.75 & 2.49 & Sandy & 21.0 & 10.1 & 4.7 \\
\hline $20-40$ & 56.72 & 39.56 & 3.72 & Sandy & 19.0 & 13.5 & 5.6 \\
\hline $40-60$ & 36.76 & 59.40 & 3.84 & Sandy & 22.0 & 12.5 & 4.6 \\
\hline
\end{tabular}

Table 3. Soil chemical properties of experimental site

\begin{tabular}{ccccc}
\hline Soil depth & $\mathbf{O M}(\boldsymbol{\%})$ & $\mathbf{p H}(\mathbf{1 : 2 . 5})$ & $\mathbf{E C ~}\left(\mathbf{d S m}^{-\mathbf{1}}\right)$ & $\mathbf{C a C O}_{\mathbf{3}}(\boldsymbol{\%})$ \\
\hline $0-20$ & 0.65 & 8.7 & 0.35 & 7.02 \\
$20-40$ & 0.40 & 8.8 & 0.32 & 2.34 \\
$40-60$ & 0.25 & 9.3 & 0.44 & 4.68 \\
\hline
\end{tabular}




\subsection{Experimental details}

The water resource for irrigation comes from an irrigation channel under rotational irrigation where the water exist in the channel just for three days every week and the residual four days the channel is empty, the idea was to expert the availability to apply water more than once per week and to evaluate its effect on water saving, irrigation water use efficiency (IWUE), yield and growth

characteristics and financial parameters using two types of sprinkler systems, solid set and hand move laterals and three irrigation frequency treatments, each treatment replicated three times.

The variables of irrigation frequency were to apply irrigation water once per week $\left(\mathrm{IF}_{1}\right)$ which represents the control, twice per week $\left.\left(\mathrm{IF}_{2}\right)\right)$ and three times per week $\left(\mathrm{IF}_{3}\right)$. The treatments and replications are shown in (Fig. 1).

For the sprinkler irrigation treatments, each replicate subplot was $60 \mathrm{~m} \times$ $24 \mathrm{~m}$ layout. There was $3 \mathrm{~m}$ spacing between subplots. Each subplot was irrigated using $90^{\circ}, 180^{\circ}$ and $360^{\circ}$ angle sprinklers, the sprinkler is a metal impact sprinkler 3/4" male (NAAN Sprinkler 233 A-S, Israel) with a discharge of $1.170 \mathrm{~m}^{3} \mathrm{~h}^{-1}$, wetted radius of $13.5 \mathrm{~m}$, working pressure of $300 \mathrm{kPa}$ and irrigation intensity of $8.10 \mathrm{mmh}^{-1}$.

The irrigation system's control unit had a two sand filters (Amiad, Israel), 3 inch inlet/outlet diameter, 36 inch vessel diameter, $35-50 \mathrm{~m}^{3} \mathrm{~h}^{-1}$ and $200 \mathrm{~kg}$ vessel weight (empty), and screen filter 200 mesh. Flow-meter and a pressure regulated valve were installed at the head of the irrigation system to measure the applied water and to control the system pressure. After the filtration system the solid set sprinkler irrigation system had 27 laterals $60 \mathrm{~m}$ long installed on a 1.944ha field (approximately, $324 \mathrm{~m}$ long and $60 \mathrm{~m}$ wide) with an average slope of $0.0 \%$.

The hand move laterals system had the same area but just 3 laterals were installed at each irrigation event with the same laterals length and sprinklers spacing.

A good procedure for the irrigator was followed when moving the lateral from one setting to the next by start moving the valve-opening elbow and the section of pipe connected to it. As soon as these pieces are in place at the new location, the valve was slightly opened so a very small stream of 
water runs out at the end of the first pipe section. As each subsequent section of pipe was put into place, the small stream of water runs through it, flushing out any soil or debris that may have been picked up during the move. The last section of pipe with its end plug in place was connected before the stream of water reaches the end and builds up pressure. Then the irrigator walks back along the lateral, correcting any plugged sprinklers, leaky gaskets, or tilted risers. After returning to the main line, the valve was opened further until the desired pressure was obtained. A quick check was applied with a pitot gauge on the first sprinkler confirms the valve adjustment. To save time on each lateral move, there is a tendency to completely open the valve and fill the line as quickly as possible. This causes water hammer at the far end of the line, so a surge plug at that end was installed.

\subsection{Cultural practice}

The experimental field was ploughed before planting. First disc harrow, then duck food was used for further preparation of the field for planting. A combined driller that facilitated concurrent application of fertilizer and seeds was used.

A wheat variety (Sakha-93) was planted on 6 December on both growing seasons 2009-2010 and 2010-2011, respectively. The driller setting was such that it is applied $250 \mathrm{~kg}$ of seed per hectare, at $5 \mathrm{~cm}$ soil depth with $13.5 \mathrm{~cm}$ row spacing.

Fertilizer applications were based on soil analysis recommendations. All treatment plots received the same amount of total fertilizer. A compound fertilizer was applied according to (Taha, et al., 1999) as follow: $285 \mathrm{~kg}$ $\mathrm{N} \mathrm{ha}{ }^{-1}$ as ammonium nitrate, ten percent applied to the soil before planting and at tillering, the remainder being applied in irrigation water, $70 \mathrm{~kg} \mathrm{P}_{2} \mathrm{O}_{5} \mathrm{ha}^{-1}$ as single superphosphate applied to the soil in two equal doses before planting and at tillering and $115 \mathrm{~kg} \mathrm{~K}_{2} \mathrm{O} \mathrm{ha}^{-1}$ as potassium sulphate applied in three doses (half applied to the soil before planting, one quarter at tillering and one quarter during the growing season in irrigation water). 


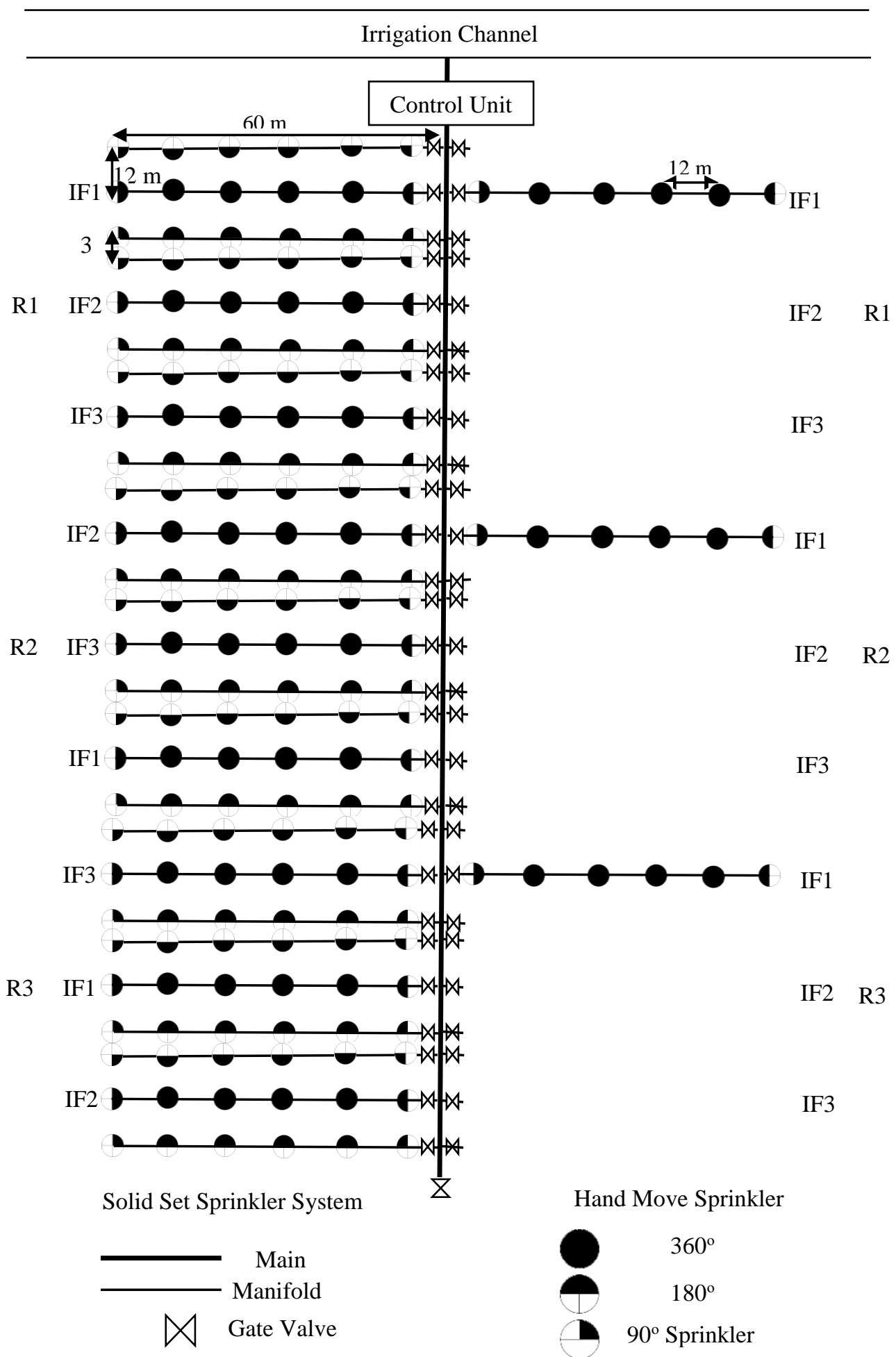

Figure 1. Experiment Layout 


\subsection{Crop parameters}

Leaf area, plant density and above ground biomass were measured every 5-7 days from December to February in each season. For each measurement, 25 plants were selected randomly from the experiment replicates for each treatment. The plant density for each treatment was determined as the mean value of three $1 \mathrm{~m}$ long crop samples. Leaf area was determined using the leaf length and the maximum width. The calibrated relationship between the leaf area and the length and width was $\mathrm{LA}=0.7634 \times \mathrm{L} \times \mathrm{W}\left(\mathrm{R}^{2}=0.967, \mathrm{n}=18\right)$, where $\mathrm{LA}$ is leaf area, $\mathrm{L}$ and $\mathrm{W}$ are length and maximum width, respectively, $\mathrm{n}$ is the number of leaves. Crop yield for each treatment was measured by randomly collecting five samples. Therefore, each treatment has 15 samples for the three replicates. Each sample area was $1 \mathrm{~m}^{2}$.

\subsection{Soil Moisture Monitoring}

Soil water was measured daily using a profile probe calibrated by using the gravimetric method. The TDR Profile Probe consists of a sealed polycarbonate rod $(\approx 25 \mathrm{~mm}$ diameter), with electronic sensors (seen as pairs of stainless steel rings) arranged at fixed intervals along its length. Irrigation was carried out between 7:00 $\mathrm{h}$ am and 12:00 $\mathrm{h}$, based on the readings from the TDR. The soil moisture distribution pattern was plotted according to daily measurements of soil moisture content before and after irrigation for one week.

To draw the soil moisture distribution as contour lines and the soil water movement within the whole soil profile, surfer software was used. Surfer is a software package transforms 3D data to create contour maps. The data was inserted to the model in XYZ coordinates format, where $\mathrm{X}$ represented the profile probe access tubes locations or sites $(0,2,4,6,8$, 10 and $12 \mathrm{~m})$ with respect to the sprinkler, Y represented the investigated soil depths $(0,10,20,30,40 \mathrm{~cm})$ which represents the effective root depth, and $\mathrm{Z}$ was the soil moisture content values.

\subsection{Data Recording}

Weather data was recorded from an adjacent weather station. Growth and development parameters such as plant height, leaf area and reproductive parameters. The dry matter data for leaf, stem, and roots was derived 
from final plant harvest. Evapotranspiration (ET) was calculated with the water balance equation (Eq. (1)):

$$
\mathrm{ET}=\mathrm{I}+\mathrm{P} \pm \Delta \mathrm{SW}-\mathrm{Dp}-\mathrm{R}
$$

Where ET is the evapotranspiration $(\mathrm{mm})$, I the amount of irrigation water applied $(\mathrm{mm}), \Delta \mathrm{SW}$ the soil water content changes $(\mathrm{mm}), \mathrm{Dp}$ the deep percolation $(\mathrm{mm})$, and $\mathrm{R}$ is the amount of runoff $(\mathrm{mm})$. Since the amount of irrigation water was controlled, deep percolation and runoff were assumed to be negligible.

Water-use efficiency (WUE) and irrigation water-use efficiency (IWUE) values were calculated with Eqs. (2) and (3), respectively (Howell et al., 1990).

$$
\mathrm{WUE}=\left(\frac{E_{y}}{E_{t}}\right) \times 100
$$

Where WUE is the water use efficiency ( $\left.\mathrm{ha}^{-1} \mathrm{~mm}\right)$; $\mathrm{E}_{\mathrm{y}}$ is the economical yield $\left(\mathrm{t} \mathrm{ha}^{-1}\right) ; \mathrm{E}_{\mathrm{t}}$ is the plant water consumption, $\mathrm{mm}$.

$$
I \mathrm{WUE}=\left(\frac{\mathrm{E}_{\mathrm{y}}}{\mathrm{I}_{\mathrm{r}}}\right) \times 100
$$

Where IWUE is the irrigation water use efficiency $\left(\mathrm{t} \mathrm{ha}^{-1} \mathrm{~mm}\right), \mathrm{E}_{\mathrm{y}}$ is the economical yield $\left(\mathrm{t} \mathrm{ha} \mathrm{h}^{-1}\right), \mathrm{I}_{\mathrm{r}}$ is the amount of applied irrigation water $(\mathrm{mm})$.

Nitrogen use efficiency (NUE) is an important topic when discussing fertilizer application and plant growth. Nitrogen use efficiency is defined as production per unit of $\mathrm{N}$ available in the soil. This is represented by the amount of grain or forage produced divided by the amount of $\mathrm{N}$ supplied to the plant by the soil (Moll et al., 1982). The same way of calculating NUE was applied for calculating phosphate use efficiency (PUE) and potassium use efficiency (KUE).

Leaf area was calculated by multiplying leaf length by maximum leaf width by 0.75 according to Stickler et al (1961).

The chlorophyll was measured by using "Minolta Chlorophyll Meter", SPAD-502 (Spectrum Technologies). 
Protein content as a percentage was determined by multiplying N-content in seeds by 6.25 according to Chapman and Pratt (1978).

\subsection{Evaluation Parameters}

Uniformity of irrigation water distribution under square layout was measured three times by using containers with $20 \mathrm{~cm}$ in diameter and $7 \mathrm{~cm}$ in depth placed along the two diagonals at intervals of $1 \mathrm{~m}$ before each measurement. The coefficient of uniformity, computed using Christiansen method (Christiansen, 1942), ranged from 0.85 to 0.92 under low wind conditions (less than $2.0 \mathrm{~ms}^{-1}$ ).

$$
C U=100\left(1.0-\frac{\sum_{i=1}^{n}|z-m|}{\sum_{i=1}^{n} z}\right)
$$

Where $\mathrm{CU}$ is the Christiansen uniformity coefficient, $\mathrm{z}$ is the individual depth of catch observations from uniformity test $(\mathrm{mm})$, $\mathrm{m}$ is the mean depth of observations ( $\mathrm{mm}$ ) and $\mathrm{n}$ is the number of observations (Keller and Bliesner, 1990).

\subsection{Statistical Analyses}

Statistical analysis was done by standard analysis of variance (ANOVA) with SPSS 11.5 software (SPSS Inc., Chicago, IL, USA). Least significant difference (LSD) method was used to determine whether differences existed among mean growth characteristic, yield, WUE and IWUE of winter wheat among experimental treatments for each season. The probability level for determination of significance was 0.05 .

\subsection{Irrigation}

\section{RESULTS AND DISCUSSION}

The results of total irrigation water amount are shown in Table 4. Treatments $S_{1} I_{1}$ and $S_{2} I_{1}$ received the lowest amount of water and treatments $\mathrm{S}_{1} \mathrm{IF}_{3}$ and $\mathrm{S}_{2} \mathrm{IF}_{3}$ received the highest amount of water, respectively, throughout the entire experiment.

Total irrigation water amount (I) was in general higher in the treatments irrigated with high amount of water than those irrigated with low amount of water. Irrigation water amount (I) values of the $\mathrm{IF}_{3}$ treatment were higher than those of the $\mathrm{IF}_{1}$ and $\mathrm{IF}_{2}$ treatments under both sprinkler irrigation systems (Table 4). This might be because plants were not suffered from water deficit in short irrigation intervals. According to 
Radin et al. (1989), frequent irrigations prevent the large fluctuation in plant water stress caused by infrequent irrigations.

\subsection{Wheat yield}

The biological and grain yield of wheat based on 2 years, irrigation frequencies and sprinkler irrigation systems are given in Table 4. There was a statistically no significant difference in biological and grain yield between the years $(\mathrm{P}<0.05)$ possibly due to that there was not a notable climate differences. The effect of irrigation frequency was statistically significant effects $(\mathrm{P}<0.05)$ on wheat yield. The maximum grain yield of wheat was found in 2010-2011 (6000 kg.ha-1) under $\mathrm{S}_{1} \mathrm{IF}_{3}$ treatment whereas the lowest grain yield was found in 2009-2010 (3332.500 kg.ha${ }^{1}$ ) under $S_{2} I_{F}$ treatment (Table 4).

Table 4. Total irrigation water amount (I), plant water consumption (ET), Biological yield, grain yield, irrigation water use efficiency and water use efficiency in different years and treatments

\begin{tabular}{|c|c|c|c|c|c|c|c|}
\hline $\begin{array}{l}\text { Growing } \\
\text { season }\end{array}$ & Treatments & $\begin{array}{c}\mathbf{I} \\
\left(\mathbf{m}^{3} / \mathbf{h a}\right)\end{array}$ & $\begin{array}{c}\text { ET } \\
\left(\mathbf{m}^{3} / \mathbf{h a}\right)\end{array}$ & $\begin{array}{c}\text { Biological } \\
\text { yield } \\
(\mathbf{K g} / \mathbf{h a})\end{array}$ & $\begin{array}{c}\text { Grain } \\
\text { yield } \\
\text { (Kg/ha) }\end{array}$ & $\begin{array}{c}\text { IWUE } \\
\left(\mathbf{k g} / \mathbf{m}^{3}\right)\end{array}$ & $\begin{array}{c}\text { WUE } \\
\left(\mathbf{k g} / \mathrm{m}^{3}\right)\end{array}$ \\
\hline \multirow[t]{7}{*}{$2009-2010$} & $\overline{\mathrm{S}_{1} \mathrm{IF}_{1}}$ & 4558.160 & 4513.029 & $9917.500 \mathrm{c}$ & $3917.50 \mathrm{~cd}$ & $0.859 \mathrm{~d}$ & $0.868 \mathrm{a}$ \\
\hline & $\mathrm{S}_{1} \mathrm{IF}_{2}$ & 4666.763 & 4620.557 & $12250.000 \mathrm{~b}$ & $5082.500 \mathrm{~b}$ & $1.089 \mathrm{~b}$ & $1.100 \mathrm{~d}$ \\
\hline & $\mathrm{S}_{1} \mathrm{IF}_{3}$ & 4946.594 & 4897.618 & $13917.500 \mathrm{a}$ & $5832.500 \mathrm{a}$ & $1.179 \mathrm{a}$ & $1.191 \mathrm{~b}$ \\
\hline & $\mathrm{S}_{2} \mathrm{IF}_{1}$ & 4694.904 & 4648.420 & $7417.500 \mathrm{~d}$ & $3332.500 \mathrm{~d}$ & $0.710 \mathrm{e}$ & $0.717 \mathrm{~b}$ \\
\hline & $\mathrm{S}_{2} \mathrm{IF}_{2}$ & 4806.766 & 4759.174 & $10000.000 \mathrm{c}$ & $4167.500 \mathrm{c}$ & $0.867 \mathrm{c}$ & $0.876 \mathrm{~d}$ \\
\hline & $\mathrm{S}_{2} \mathrm{IF}_{3}$ & 5094.992 & 5044.546 & $12582.500 \mathrm{~b}$ & $5082.500 \mathrm{~b}$ & $0.998 \mathrm{~b}$ & $1.008 \mathrm{c}$ \\
\hline & L.S.D. & $\mathrm{ns}$ & ns & 0.532 & 0.248 & 0.03238 & 0.01603 \\
\hline \multirow[t]{7}{*}{$2010-2011$} & $\mathrm{~S}_{1} \mathrm{IF}_{1}$ & 4792.457 & 4745.007 & $9832.500 \mathrm{c}$ & $3750.00 \mathrm{~cd}$ & $0.782 \mathrm{~d}$ & $0.790 \mathrm{e}$ \\
\hline & $\mathrm{S}_{1} \mathrm{IF}_{2}$ & 5041.229 & 4991.316 & $12417.500 \mathrm{~b}$ & $5250.000 \mathrm{~b}$ & $1.041 \mathrm{~b}$ & $1.052 \mathrm{~b}$ \\
\hline & $\mathrm{S}_{1} \mathrm{IF}_{3}$ & 5210.708 & 5159.117 & $13832.500 \mathrm{a}$ & $6000.000 \mathrm{a}$ & $1.151 \mathrm{a}$ & $1.163 \mathrm{a}$ \\
\hline & $\mathrm{S}_{2} \mathrm{IF}_{1}$ & 4888.306 & 4839.907 & $7500.000 \mathrm{~d}$ & $3417.500 \mathrm{~d}$ & $0.699 \mathrm{e}$ & $0.706 \mathrm{f}$ \\
\hline & $\mathrm{S}_{2} \mathrm{IF}_{2}$ & 5142.054 & 5091.142 & $10082.500 \mathrm{c}$ & $4417.500 \mathrm{c}$ & $0.859 \mathrm{c}$ & $0.868 \mathrm{~d}$ \\
\hline & $\mathrm{S}_{2} \mathrm{IF}_{3}$ & 5471.243 & 5417.073 & $12667.500 \mathrm{~b}$ & $5250.000 \mathrm{~b}$ & $0.960 \mathrm{~b}$ & $0.969 \mathrm{c}$ \\
\hline & L.S.D. & $\mathrm{ns}$ & ns & 0.531 & 0.247 & 0.02921 & 0.00907 \\
\hline $2009-2010$ & & 4794.696 & 4747.224 & 11014.167 & 4569.167 & 0.950 & 0.960 \\
\hline $2010-2011$ & & 5091.000 & 5040.594 & 11055.417 & 4680.833 & 0.916 & 0.925 \\
\hline L.S.D. & & 0.001 & 0.010 & ns & ns & 0.001 & 0.008 \\
\hline
\end{tabular}

Note: Numbers followed by different letters are statistically different $(\mathrm{P}<0.05)$. 


\subsection{Irrigation water use efficiency}

Applied irrigation water varied from 4558.160 to $5094.992 \mathrm{~m}^{3} \cdot \mathrm{ha}^{-1}$ in 2009-2010, and 4792.457 to $5471.243 \mathrm{~m}^{3} \cdot \mathrm{ha}^{-1}$ in 2010-2011. IWUE values varied from 0.0 .710 to $1.179 \mathrm{~kg} \cdot \mathrm{m}^{-3}$ in $2009-2010$ and from 0.699 to $1.151 \mathrm{~kg} \cdot \mathrm{m}^{-3}$ in $2010-2011$. WUE values varied from 0.717 to $1.191 \mathrm{~kg} \cdot \mathrm{m}^{-3}$ in 2009-2010 and from 0.706 to $1.163 \mathrm{~kg} \cdot \mathrm{m}^{-3}$ in 2010-2011. On the other hand, IWUE and WUE values in the treatments with the high total water application were generally high. The irrigation water use efficiency data showed that wheat plants use water efficiently during the vegetation period.

The ET value increased markedly when total irrigation water amount (I) was raised (Table 4). The highest seasonal evapotranspiration was obtained from the $\mathrm{S}_{2} \mathrm{IF}_{3}$ treatment in 2009-2010 (5044.546 $\left.\mathrm{m}^{3} \cdot \mathrm{ha}^{-1}\right)$, whereas the lowest value was obtained from the $S_{1} I_{1}$ treatment in the same growing season $\left(4513.029 \mathrm{~m}^{3} / \mathrm{ha}\right)$. The other treatments had ET values between these extremities.

There was a statistically significant difference in total irrigation water amount (I), plant water consumption (ET), irrigation water use efficiency (IWUE) and water use efficiency (WUE) between the years $(\mathrm{P}<0.05)$.

Kanber et al. (1991) reported that the amount of irrigation water decreased when IWUE and WUE values increased. Studies have shown that frequently applied low irrigation water increases the yield because ET was higher when irrigation started at low soil water tensions (Stansell and Smittle, 1989). Goldberg et al. (1976) stated that irrigation period was more effective than the total amount of water applied, when plants were irrigated with a limited amount of water in early growth stage because of higher photosynthetic efficiency and vegetative growth. In this study, IWUE and WUE values from $S_{1} I_{1}$ to $S_{1} I_{3}$ and from $S_{2} I F_{1}$ to $\mathrm{S}_{2} \mathrm{IF}_{3}$ have been generally increased. This indicates that wheat uses water economically. These findings agree with those of Dallyn (1983).

On over all the values of solid set sprinkler $\left(\mathrm{S}_{1}\right)$ were higher than of those under hand move laterals $\left(\mathrm{S}_{2}\right)$ which represented the applied systems by 
farmers. This is related to that, the distribution uniformity under hand move laterals which was low because there was an overlapping just between sprinklers along laterals not overlapping between sprinklers along laterals and between laterals which made a square plan. The second reason is related to the long irrigation period related to transform lateral to another location which make an obligation to irrigate under high temperature and which accordingly increase water losses through evaporation. On the other hand sold set sprinkler $\left(S_{1}\right)$ was irrigated the whole area at the same time approximately from 7:00 to 9:00 am so the water losses through evaporation were almost negligible.

\subsection{Vegetative growth parameters}

Plant height values varied from a low of $115.17 \mathrm{~cm}$ to maximum of $123.17 \mathrm{~cm}$ in the experimental years. Plant height increased with increasing irrigation frequency (Table 5). Highest plant height value was obtained from $\mathrm{S}_{1} \mathrm{IF}_{3}$ in the experimental years. Plant height decreased with decreasing irrigation frequency under both sprinkler systems.

The mean number of leaves per plant values varied from a low of 3.667 to maximum of 6.00 in the experimental years (Table 5). Highest number of leaves per plant was obtained from $\mathrm{S}_{1} \mathrm{IF}_{3}$ for both growing seasons. The number of leaves per plant values decreased with decreasing irrigation frequency.

Flag leaf area per plant varied from 20.667 to $31.667 \mathrm{~cm}^{2}$ in $2009-2010$, and 21 to $31.333 \mathrm{~cm}^{2}$ in 2010-2011. The highest flag leaf area was obtained under $\mathrm{S}_{1} \mathrm{IF}_{3}$ treatment and the lowest flag leaf area was obtained under $\mathrm{S}_{2} \mathrm{IF}_{1}$. The flag leaf area increased with increasing irrigation frequency and it was higher under solid set sprinkler $\left(\mathrm{S}_{1}\right)$ compared with hand move laterals $\left(\mathrm{S}_{2}\right)$ (Table 5).

Dry weight per plant varied from 4.233 to $5.333 \mathrm{~g}$ in 2009-2010, and 4 to $5.4 \mathrm{~g}$ in 2010-2011. The highest dry weight value was obtained under $\mathrm{S}_{1} \mathrm{IF}_{3}$ and the lowest value was obtained under $\mathrm{S}_{2} \mathrm{IF}_{1}$. 
Table 5. The vegetative growth parameters of wheat in different years and treatments

\begin{tabular}{|c|c|c|c|c|c|c|c|}
\hline $\begin{array}{l}\text { Growing } \\
\text { season }\end{array}$ & Treatments & $\begin{array}{l}\text { Plant } \\
\text { height } \\
(\mathbf{c m})\end{array}$ & $\begin{array}{l}\text { Number } \\
\text { of leaves }\end{array}$ & $\begin{array}{c}\text { Flag Leaf } \\
\text { area } \\
\left(\mathrm{cm}^{2}\right)\end{array}$ & $\begin{array}{l}\text { Dry weight } \\
\text { per plant } \\
\text { (g) }\end{array}$ & $\begin{array}{c}\text { Protein } \\
\text { Content } \\
(\%)\end{array}$ & $\begin{array}{c}\text { Total } \\
\text { Chlorophyll } \\
(\%)\end{array}$ \\
\hline \multirow[t]{7}{*}{$2009-2010$} & $\mathrm{~S}_{1} \mathrm{IF}_{1}$ & $117.90 \mathrm{~b}$ & $4.333 \mathrm{c}$ & $22.000 \mathrm{bc}$ & $4.233 \mathrm{c}$ & $10.433 \mathrm{~cd}$ & $29.700 \mathrm{~d}$ \\
\hline & $\mathrm{S}_{1} \mathrm{IF}_{2}$ & $121.17 \mathrm{a}$ & $5.667 \mathrm{ab}$ & $29.333 \mathrm{a}$ & $5.100 \mathrm{ab}$ & $12.100 \mathrm{ab}$ & $37.000 \mathrm{~b}$ \\
\hline & $\mathrm{S}_{1} \mathrm{IF}_{3}$ & $123.17 \mathrm{a}$ & $6.000 \mathrm{a}$ & $31.667 \mathrm{a}$ & $5.333 \mathrm{a}$ & $12.700 \mathrm{a}$ & $43.067 \mathrm{a}$ \\
\hline & $\mathrm{S}_{2} \mathrm{IF}_{1}$ & $115.17 \mathrm{~d}$ & $3.667 \mathrm{c}$ & $20.667 \mathrm{c}$ & $3.600 \mathrm{~d}$ & $10.067 \mathrm{~d}$ & $24.067 \mathrm{e}$ \\
\hline & $\mathrm{S}_{2} \mathrm{IF}_{2}$ & $116.60 \mathrm{bc}$ & $4.333 \mathrm{c}$ & $24.333 \mathrm{~b}$ & $4.667 \mathrm{bc}$ & $10.833 \mathrm{c}$ & $32.067 \mathrm{c}$ \\
\hline & $\mathrm{S}_{2} \mathrm{IF}_{3}$ & $117.17 \mathrm{bc}$ & $5.167 \mathrm{~b}$ & $29.667 \mathrm{a}$ & $4.767 \mathrm{abc}$ & $11.700 \mathrm{~b}$ & $37.300 \mathrm{~b}$ \\
\hline & L.S.D. & 2.541 & 0.755 & 2.828 & 0.596 & 0.631 & 1.357 \\
\hline \multirow[t]{7}{*}{$2010-2011$} & $\mathrm{~S}_{1} \mathrm{IF}_{1}$ & $118.67 \mathrm{c}$ & $4.667 \mathrm{bc}$ & $22.667 \mathrm{bc}$ & $4.667 \mathrm{c}$ & $10.433 \mathrm{e}$ & $29.433 \mathrm{~d}$ \\
\hline & $\mathrm{S}_{1} \mathrm{IF}_{2}$ & $121.00 \mathrm{a}$ & $5.333 \mathrm{a}$ & $28.333 \mathrm{a}$ & $5.100 \mathrm{ab}$ & $12.000 \mathrm{~b}$ & $37.700 \mathrm{~b}$ \\
\hline & $\mathrm{S}_{1} \mathrm{IF}_{3}$ & $121.33 \mathrm{ab}$ & $6.000 \mathrm{a}$ & $31.333 \mathrm{a}$ & $5.400 \mathrm{a}$ & $12.733 \mathrm{a}$ & $42.867 \mathrm{a}$ \\
\hline & $\mathrm{S}_{2} \mathrm{IF}_{1}$ & $115.33 \mathrm{~d}$ & $4.000 \mathrm{c}$ & $21.000 \mathrm{c}$ & $4.000 \mathrm{~d}$ & $10.200 \mathrm{f}$ & $25.333 \mathrm{e}$ \\
\hline & $\mathrm{S}_{2} \mathrm{IF}_{2}$ & $117.00 \mathrm{~b}$ & $4.667 \mathrm{~b}$ & $25.333 \mathrm{~b}$ & $4.567 \mathrm{bc}$ & $10.800 \mathrm{~d}$ & $32.367 \mathrm{c}$ \\
\hline & $\mathrm{S}_{2} \mathrm{IF}_{3}$ & $117.67 \mathrm{bc}$ & $4.667 \mathrm{a}$ & $26.667 \mathrm{a}$ & $4.867 \mathrm{~b}$ & $11.533 \mathrm{c}$ & $38.233 \mathrm{~b}$ \\
\hline & L.S.D. & 0.492 & 2.828 & 2.828 & 0.492 & 0.304 & 1.160 \\
\hline $2009-2010$ & & 119.863 & 4.861 & 26.278 & 4.617 & 11.306 & 33.867 \\
\hline 2010-2011 & & 118.500 & 4.889 & 25.889 & 4.767 & 11.283 & 34.322 \\
\hline L.S.D. & & ns & ns & ns & $\mathrm{ns}$ & $\mathrm{ns}$ & ns \\
\hline
\end{tabular}

Note: Numbers followed by different letters are statistically different $(\mathrm{P}<0.05)$.

The protein content varied from 10.067 to $12.700 \%$ in $2009-2010$, and 10.20 to $12.733 \%$ in 2010-2011. Protein content and total chlorophyll had the highest values under $\mathrm{S}_{1} \mathrm{IF}_{3}$ and the lowest values were obtained under $\mathrm{S}_{2} \mathrm{IF}_{3}$. The values of protein content and total chlorophyll under solid set sprinkler $\left(S_{1}\right)$ were higher than of those under hand move laterals $\left(S_{2}\right)$ and the protein content decreased with decreasing irrigation frequency.

There was a statistically significant difference in plant height, number of leaves per plant, flag leaf area, dry weight per plant, protein content and total chlorophyll between treatments but there was a statistically no significant difference between experimental years $(\mathrm{P}<0.05)$.

\subsection{Nutrient use efficiency}


There were significant differences in the nitrogen, phosphorus and potassium use efficiency among the studied sprinkler irrigation systems and irrigation frequencies during both seasons of study but there was a statistically no significant difference between experimental years $(\mathrm{P}<$ 0.05) (Table 6).

The highest NUE, PUE and KUE were obtained under $\mathrm{S}_{1} \mathrm{IF}_{3}$ and the lowest values were obtained under $\mathrm{S}_{2} \mathrm{IF}_{1}$. There was a direct relationship between irrigation frequency and the NUE, PUE and KUE under the two types of sprinkler irrigation systems.

The NUE varied from 14.80 to 25.967 in 2009-2010, and 15.20 to 6.70 in 2010-2011, on the other hand the PUE values varied from 44.433 to 78.133 in 2009-2010, and 45.560 to 80 in 2010-2011, while the values of KUE varied from 56.233 to 97 in 2009-2010, and 56.933 to 100 in 20102011.

The high the nutrient use efficiency the high the yield obtained, in this regard, the highest yield obtained under $S_{1} I_{3}$ where the highest nutrient use efficiencies were adopted. Similarly the lowest yield was under $S_{2} I F_{1}$ where the lowest NUE, PUE and KUE were obtained.

Table 6. The fertilizers use efficiency of wheat in different years and treatments

\begin{tabular}{|c|c|c|c|c|}
\hline Growing season & Treatments & NUE & PUE & KUE \\
\hline \multirow[t]{7}{*}{$2009-2010$} & $\mathrm{~S}_{1} \mathrm{IF}_{1}$ & $17.800 \mathrm{c}$ & $53.667 \mathrm{c}$ & $66.667 \mathrm{c}$ \\
\hline & $\mathrm{S}_{1} \mathrm{IF}_{2}$ & $22.567 \mathrm{~b}$ & $67.800 \mathrm{~b}$ & $84.700 \mathrm{~b}$ \\
\hline & $\mathrm{S}_{1} \mathrm{IF}_{3}$ & $25.967 \mathrm{a}$ & $78.133 \mathrm{a}$ & $97.200 \mathrm{a}$ \\
\hline & $\mathrm{S}_{2} \mathrm{IF}_{1}$ & $14.800 \mathrm{~d}$ & $44.433 \mathrm{~d}$ & $56.233 \mathrm{~d}$ \\
\hline & $\mathrm{S}_{2} \mathrm{IF}_{2}$ & $18.533 \mathrm{c}$ & $54.567 \mathrm{c}$ & $69.433 \mathrm{c}$ \\
\hline & $\mathrm{S}_{2} \mathrm{IF}_{3}$ & $22.567 \mathrm{~b}$ & $67.800 \mathrm{~b}$ & $84.700 \mathrm{~b}$ \\
\hline & L.S.D. & 1.124 & 2.114 & 3.351 \\
\hline \multirow[t]{7}{*}{$2010-2011$} & $\mathrm{~S}_{1} \mathrm{IF}_{1}$ & $16.700 \mathrm{c}$ & $50.000 \mathrm{c}$ & $62.500 \mathrm{c}$ \\
\hline & $\mathrm{S}_{1} \mathrm{IF}_{2}$ & $23.300 \mathrm{~b}$ & $70.000 \mathrm{~b}$ & $87.500 \mathrm{~b}$ \\
\hline & $\mathrm{S}_{1} \mathrm{IF}_{3}$ & $26.700 \mathrm{a}$ & $80.000 \mathrm{a}$ & $100.000 \mathrm{a}$ \\
\hline & $\mathrm{S}_{2} \mathrm{IF}_{1}$ & $15.200 \mathrm{~d}$ & $45.560 \mathrm{~d}$ & $56.933 \mathrm{~d}$ \\
\hline & $\mathrm{S}_{2} \mathrm{IF}_{2}$ & $19.633 \mathrm{c}$ & $58.867 \mathrm{c}$ & $73.633 \mathrm{c}$ \\
\hline & $\mathrm{S}_{2} \mathrm{IF}_{3}$ & $23.300 \mathrm{~b}$ & $70.000 \mathrm{~b}$ & $87.500 \mathrm{~b}$ \\
\hline & L.S.D. & 1.124 & 1.868 & 3.510 \\
\hline $2009-2010$ & & 20.372 & 61.067 & 76.489 \\
\hline $2010-2011$ & & 20.806 & 65.773 & 78.011 \\
\hline L.S.D. & & ns & $\mathrm{ns}$ & ns \\
\hline
\end{tabular}

Note: Numbers followed by different letters are statistically different $(\mathrm{P}<0.05)$.

\subsection{Soil water content before and after irrigation}

The soil moisture distribution before irrigation was uniformly distributed at $15-30 \mathrm{~cm}$ soil layer where contour lines were approximately parallel to 
each other. Soil moisture values reached to $5 \mathrm{~cm}^{3} . \mathrm{cm}^{-3}$ at $15-20 \mathrm{~cm}$ soil depth and it decreases towards the soil surface where the soil moisture content was $3 \mathrm{~cm}^{3} . \mathrm{cm}^{-3}$ (Fig. 2).

The soil moisture distribution after irrigation was uniformly distributed at $15-37.5 \mathrm{~cm}$ soil layer where contour lines were approximately parallel to each other. Soil moisture values reached to $12 \mathrm{~cm}^{3} . \mathrm{cm}^{-3}$ around $25 \mathrm{~cm}$ soil depth and it increases towards the soil surface where the soil moisture content was higher than $\geq 14 \mathrm{~cm}^{3} \cdot \mathrm{cm}^{-3}$ (Fig. 3). However, after irrigation the soil moisture value was high below the sprinkler and reduced gradually towards the middle of the distance between sprinklers. The uniformity of soil moisture distribution and its variation from one site to another is due to soil matric potential at the same soil depth as well as to the total hydraulic potential at different soil depths because of the soil moisture movement direction.

The moisture distribution after irrigation (Fig. 3), the soil moisture content reached to $14.5 \mathrm{~cm}^{3} . \mathrm{cm}^{-3}$ at surface layer $(0-10 \mathrm{~cm})$ under $S_{1} I_{1}$ and $\mathrm{S}_{2} \mathrm{IF}_{1}$ and it decreased with increasing irrigation frequency till 13.5 $\mathrm{cm}^{3} . \mathrm{cm}^{-3}$ under $\mathrm{IF}_{3}$ for both sprinkler irrigation systems. The soil moisture content gradually decreased with increasing the soil depth reaching only to $10 \mathrm{~cm}^{3} \cdot \mathrm{cm}^{-3}$ at $40 \mathrm{~cm}$ soil depth.

The distribution uniformity of soil moisture can be assessed by using parallel contour lines as demonstrate in Fig 2 and 3 along the lateral for the two investigated measuring times before and after irrigation respectively. The distribution uniformity before irrigation demonstrate that the uniformity of soil moisture distribution is between 10 and $30 \mathrm{~cm}$. However, this was not the case after irrigation where uniformity of soil moisture distribution found between $15 \mathrm{~cm}$ and $40 \mathrm{~cm}$ soil depth.

The presented data indicated that there was a gradual increase in soil moisture content with the increment of soil depth before irrigation The upper surface layer had the lowest moisture content $3 \mathrm{~cm}^{3} . \mathrm{cm}^{-3}$. On the other hand there was an inverse relationship between soil moisture content and soil depth after irrigation, that upper surface layer had the highest moisture content $\geq 14 \mathrm{~cm}^{3} \cdot \mathrm{cm}^{-3}$, and it decreased with the increment of soil depth.

The similarity in the data obtained along laterals between the two sprinkler irrigation systems indicates that, the variation in the moisture content and distribution uniformity are totally depending on the variation in the total hydraulic potential from one layer to another within the soil profile before and after irrigation. 
Distance between sprinklers (m)

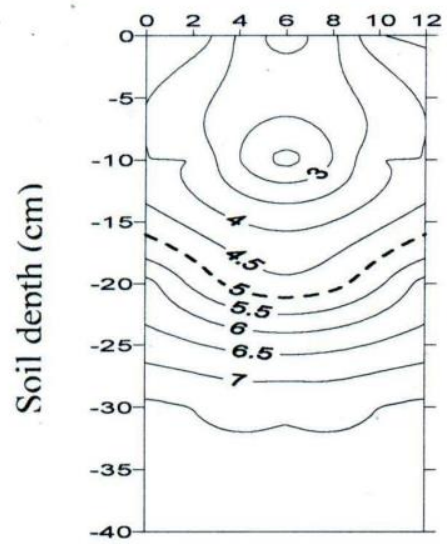

$\mathrm{S}_{1} \mathrm{IF}_{1}$

Distance between sprinklers $(\mathrm{m})$

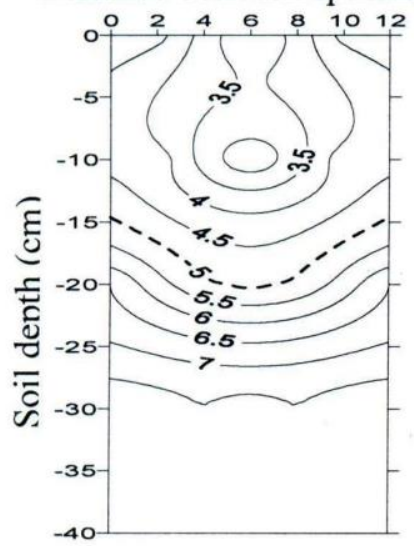

$\mathrm{S}_{1} \mathbf{I F}_{2}$

Distance between sprinklers (m)

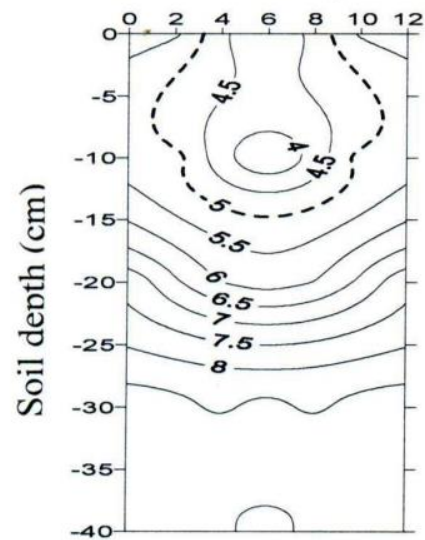

$\mathrm{S}_{1} \mathrm{IF}_{3}$
Distance between sprinklers (m)

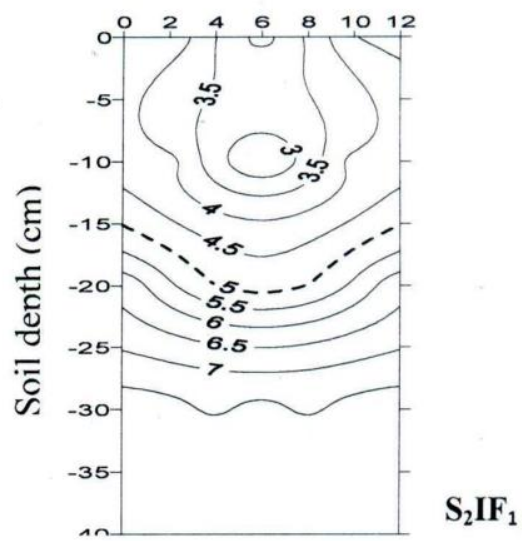

Distance between sprinklers ( $\mathrm{m}$ )

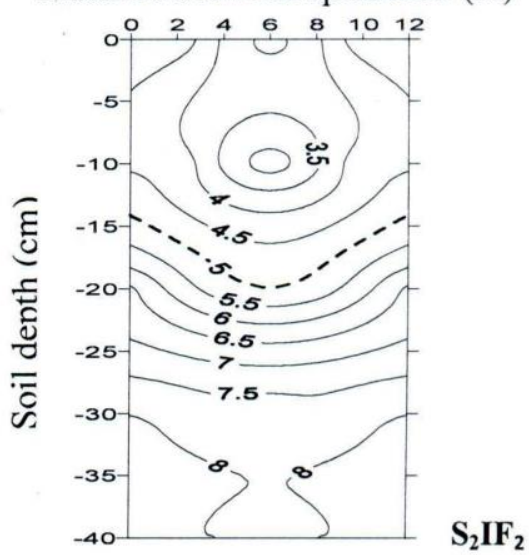

Distance between sprinklers (m)

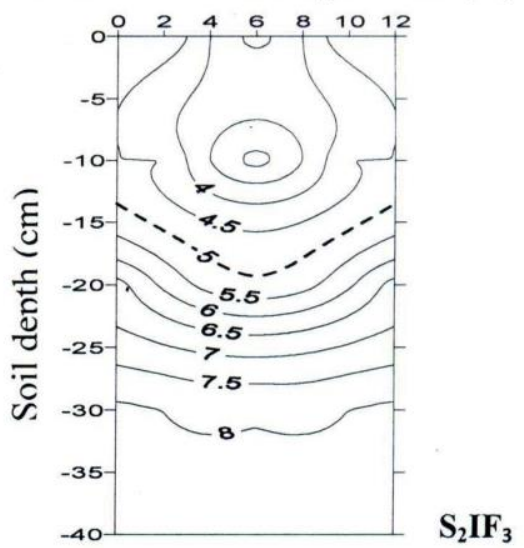

Figure 2. Volumetric soil moisture distribution before irrigation under solid set and hand move sprinkler irrigation systems for different irrigation frequency 
Distance between sprinklers (m)

Distance between sprinklers (m)

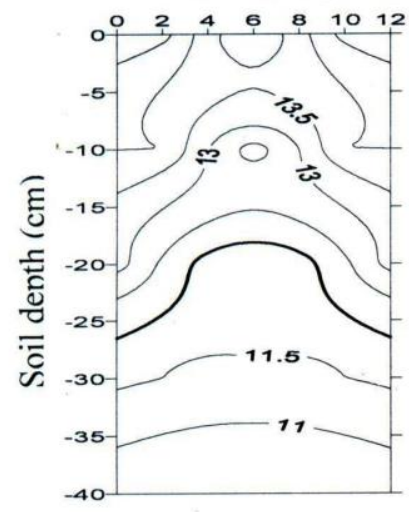

$\mathrm{S}_{1} \mathrm{IF}_{1}$

Distance between sprinklers $(\mathrm{m})$

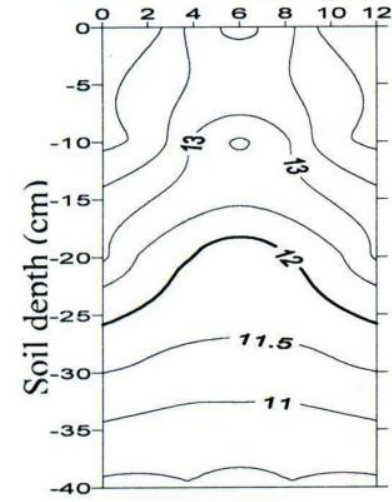

$\mathrm{S}_{1} \mathbf{I F}_{2}$

Distance between sprinklers (m)

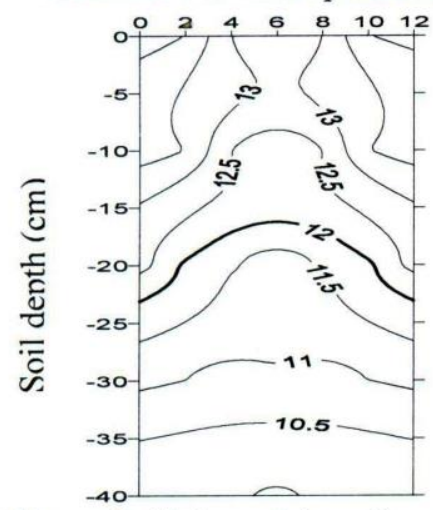

$\mathrm{S}_{1} \mathbf{I F}_{3}$

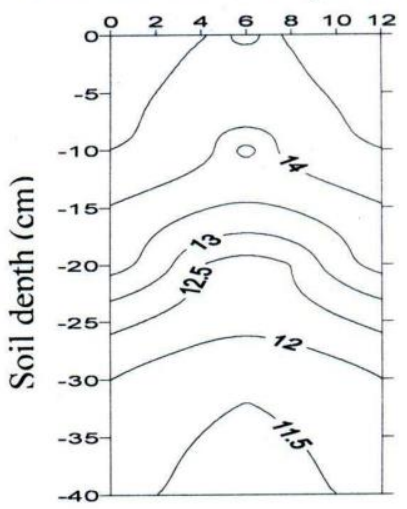

$\mathbf{S}_{2} \mathbf{I F}_{1}$

Distance between sprinklers $(\mathrm{m})$

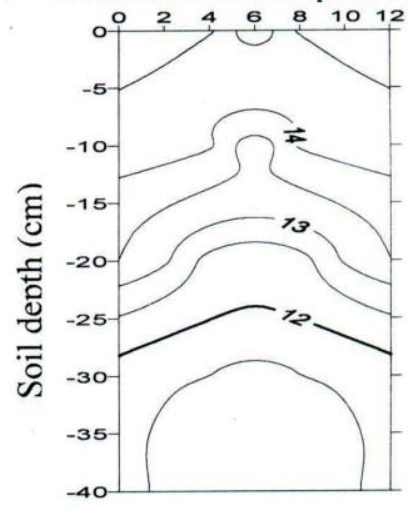

$\mathrm{S}_{2} \mathrm{IF}_{2}$

Distance between sprinklers (m)

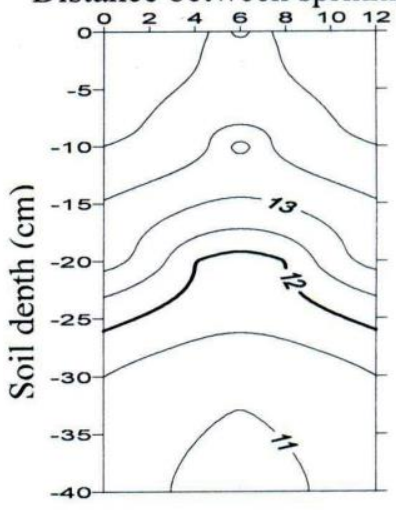

$\mathrm{S}_{2} \mathrm{IF}_{3}$

Figure 3. Volumetric soil moisture distribution immediately after irrigation under solid set and hand move sprinkler irrigation systems for different irrigation frequency

\subsection{Water stress}

The water content was close to the wilting point $\left(5 \mathrm{~cm}^{3} . \mathrm{cm}^{3}\right)$ before irrigation and higher than field capacity $\left(12 \mathrm{~cm}^{3} . \mathrm{cm}^{-}\right)$after irrigation 
(Fig. 4 and Fig. 5). $S_{1} I_{1}$ and $S_{2} I_{1}$ treatments were closer to the wilting point before irrigation and closer to field capacity after irrigation than the other treatments because of the greater amount of water per irrigation. In line with Meiri et al. (1992), plants receiving infrequent irrigation took more water from soil reserves. Soil water content of treatments irrigated with higher irrigation frequency was higher than of those with lower irrigation frequency both before and after irrigation due to the much greater amounts of applied water.

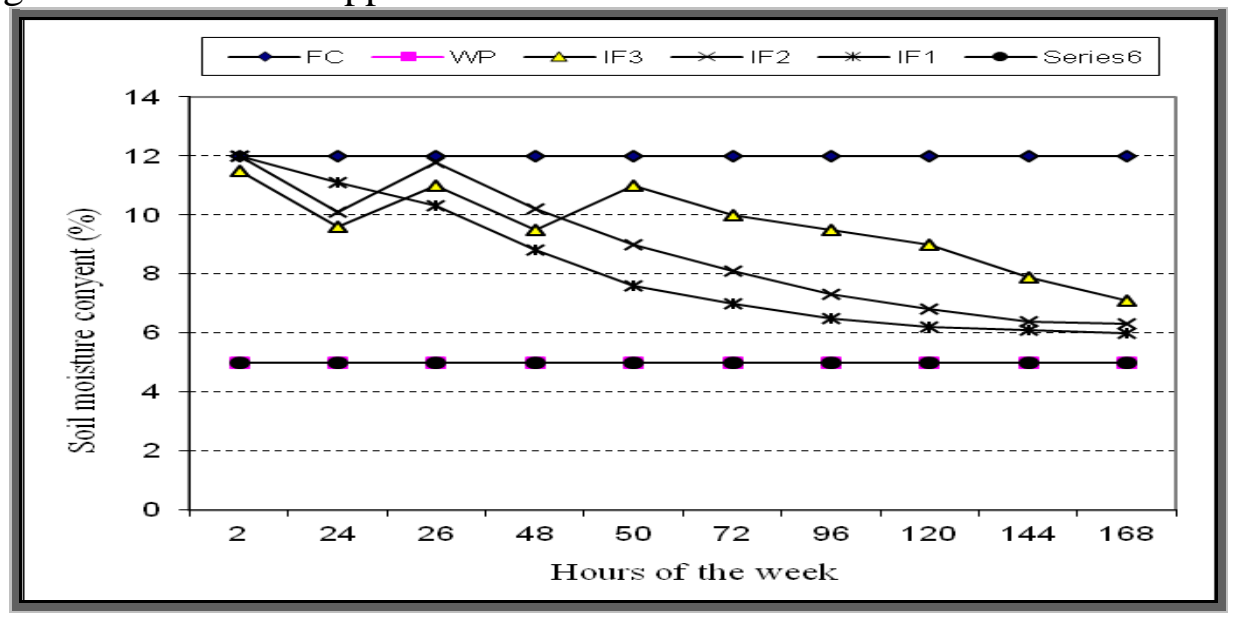

Figure 4. Water stress under solid set sprinklers for different irrigation frequency treatments

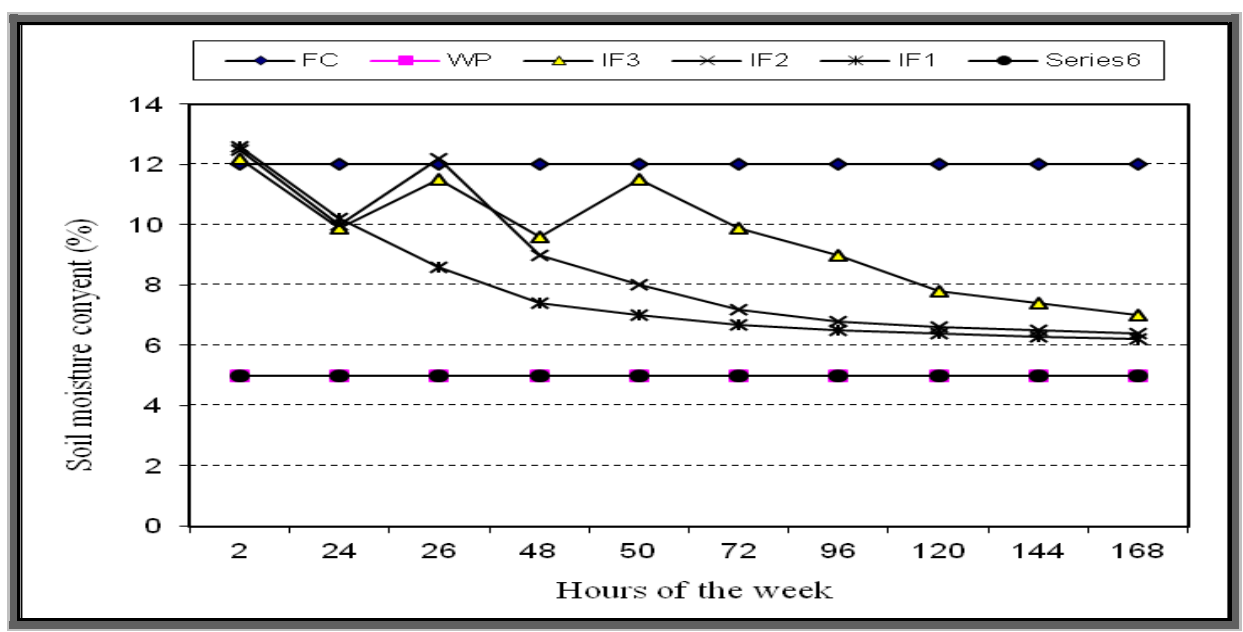

Figure 5. Water stress under hand move laterals for different irrigation frequency treatments 
As stated in Meiri et al. (1992), plants took up more water from soil in infrequently irrigated treatments. In general, soil water content before and after irrigation gradually increased towards the end of the season when temperatures were higher. This might be due to the fact that irrigation could not fully compensate for evapotranspiration (ET) loss. However, because much more water was applied with increasing irrigation frequency, the soil water content of treatments with high irrigation frequency event $\left(\mathrm{IF}_{3}\right)$ were higher than $\mathrm{IF}_{1}$ and $\mathrm{IF}_{2}$ before and after irrigations. That is why there was more water in the soil profile in the $\mathrm{IF}_{3}$ than in all the other treatments and also that is why plants does not severe from water stress under sprinkler irrigation systems with $\mathrm{IF}_{3}$ and the water stress with decreasing irrigation frequently.

\section{CONCLUSIONS}

In this study, our results demonstrate that the effect of irrigation frequency applied with a sprinkler systems and water use is significantly important in order to obtain higher yields of wheat under climatic conditions of El-Nubaria region in Egypt.

1. For sprinkler irrigation field, soil water content varied apparently in the $0-40-\mathrm{cm}$ soil layer. The water movement is totally depending on the variation in the total hydraulic potential from one layer to another within the soil profile.

2. Controlled ranges of soil water content affected all evapotranspiration, grain yield, and WUE of wheat during growing seasons. Grain yield response to irrigation varied considerably due to differences in soil moisture contents. Wheat yields obtained from solid set sprinkler irrigation in El-Nubaria region of Egypt were found to be higher than of those under hand move laterals. Highest average grain yield (6000 kg.ha $\left.{ }^{-1}\right)$ was obtained from $\left(\mathrm{S}_{1} \mathrm{IF}_{3}\right)$. Irrigation frequency affected wheat yield. The sprinkler system permitted precise control of irrigation applications. With proper management, sprinkler irrigation can avoid some application losses.

3. In areas with negligible rainfall, irrigations should be scheduled to replace water used for ET, or slightly increase it for highest yield. Yield and yield components, IWUE, WUE and dry weight per plant of 
wheat are differently affected by water stress in relation to its timing and intensity. There is no significant variations in grain yield, IWUE and WUE between seasons can be attributed to small seasonal differences in the temperature, humidity, solar radiation and wind speed during the growing stages of wheat.

4. Leaf area, number of leaves per plant, dry weight per plant, Protein content and total chlorophyll were significantly affected by irrigation frequency under both sprinkler irrigation systems. The highest yield was obtained under $S_{1} I F_{3}$ and the lowest one was under $S_{2} I_{1}$. There were no significant differences between experimental years.

5. The highest NUE, PUE and KUE were obtained under $\mathrm{S}_{1} \mathrm{IF}_{3}$ and the lowest values were obtained under $S_{2} I_{1}$. The wheat yield and vegetative growth parameters affected by the NUE, PUE and KUE.

6. For winter wheat in the El-Nubaria, the recommended sprinkler system and irrigation frequency for each event is solid set sprinkler $\left(\mathrm{S}_{1}\right)$ and irrigation three times per week $\left(\mathrm{IF}_{3}\right)$.

\section{REFERENCES}

Abuarab, M. E.; M. El-Mogy and A. M. Lotfy (2011). Response of green bean to pulse subsurface trickle irrigation. Misr Journal of Agric. Eng. 28(4): 217-236.

Alderfasi, A. A. and D. C. Nielsen (2001). Use of crop water stress index for monitoring water status and scheduling irrigation in wheat. Agricutural Water Manage 47 (1): 69-75.

Chapman, H. D. and R. F. Pratt (1978). Methods analysis for soil, plant and water. University of California Div. Agric. Sci. 16-38.

Chen, Z. (1996). Analysis on agro-meteorological effect on mulberry field under sprinkler irrigation condition. Journal Hangzhou University (Nat. Sci. Div.) 23 (1): 92-99.

Christiansen, J. E. (1942). Irrigation by sprinkling. California Agricultural Experiment Station Bulletin, P.670.

Dallyn, P. (1983). Crop water requirement under arid conditions. In: Holmes, J.C., Tahir, W.M. (Eds.), More Food from Better Technology. FAO, Rome, Italy, pp. 383-392. 
Dalvi, V. B.; K. N. Tiwari; M. N. Pawade and P. S. Phirke (1999). Response surface analysis of tomato production under microirrigation. Agricultural Water Manage 41: 11-19.

FAO (2000). Crops and drops: Making the best use of water for agriculture. FAO Advance Edition, Rome.

Freeman, B. M.; J. Blackwell and K. V. Garzoli (1976). Irrigation frequency and total water application with trickle and furrow systems. Agricultural Water Manage 1: 21-31.

Goldberg, D.; B. Gornat and D. Rimon (1976). Drip irrigation principles design and agricultural practices. Drip Irrig. Sci. Pub., Israel, p. 295.

Haijun, L.; Y. Lipeng; L. Yu; W. Xiangping and H. Guanhua (2011). Responses of winter wheat (Triticum aestivum L.) evapotranspiration and yield to sprinkler irrigation regimes. Agricultural Water Management 98: 483-492.

Howell, T. A.; R. H. Cuence and K. H. Solomon (1990). Crop yield response. In: Hoffman GJ., et al. (Eds.), Management of farm irrigation systems. ASAE, St. Joseph, MI; p. 312.

Kanber, R.; O. Tekinel; N. Baytorun and Y. Kumova (1991). Estimation of the most suitable irrigation frequencies and quantities in cotton in harran plain by using free pan evaporation coefficient, 44. The Republic of Turkey Prime Ministry GAP-Regional Development Adminstration, GAP Publications, pp. 15-25.

Keller, J. and R. D. Bliesner (1990). Sprinkler and trickle irrigation. Van Nostrand Reinhold, New York.

Li, J. and M. Rao (2003). Field evaluation of crop yield as affected by nonuniformity of sprinkler-applied water and fertilizers. Agricultural Water Manage 59: 1-13.

Meiri, A.; H. Frenkel and A. Mantell (1992). Cotton response to water and salinity under and drip irrigation. Am. Soc. Agron., Madision, WI 84 (1): 44-50. 
Mishra, H. S.; T. R. Rathore and V. S. Tomar (1995). Water use efficiency of irrigated wheat in the Terai region of India. Irrigation Science 16: 75-80.

Moll, R. H.; E. J. Kamprath and W. A. Jackson (1982). Analysis and interpretation of factors which contribute to efficiency of nitrogen utilization. Agronomy Journal 74: 562-564.

Radin, J. W.; J. R. Mauney and P. C. Kerridge (1989). Water uptake by cotton roots during fruit filling in relation to irrigation frequency. Crop Sci. 29: 1000-1005.

Rosegrant, M. W. and X. Cai (2000). Modeling water availability and food security-a global perspective: The IMPACT-Water Model. Working Draft. International Food Policy Research Institute, Washington, DC.

Segal, E.; A. Ben-Gal and U. Shani (2000). Water availability and yield response to high-frequency micro-irrigation in sunflowers. In: Proceedings of the Sixth International Micro-irrigation Congress on 'Micro-irrigation Technology for Developing Agriculture', Conference Papers, 22-27 October, South Africa.

Seregeldin, I. (1999). Looking ahead: water, life and the environment in the 21 st century. Journal of International Water Resources Dev. 15 (1 and 2): 17-27.

Sharmasarkar, F. C.; S. Sharmasarkar; S. D. Miller; G. F. Vance and R. Zhang (2001). Assessment of drip irrigation and flood irrigation on water and fertilizer use efficiencies for sugarbeets. Agricultural Water Manage 46: 241-251.

Silber, A.; G. Xu; I. Levkovitch; S. Soriano; A. Bilu and R. Wallach (2003). High fertigation frequency: the effects on uptake of nutrients, water and plant growth. Plant and Soil 253:467-477.

Stansell, J. R. and D. A. Smittle (1989). Effects of irrigation regimes on yield and water use in summer squash. J. Am. Soc. Hort. Sci. 114 (2): 196-199. 
Stickler, F.; C. Weaden and A. W. Pauli (1961). Leaf area determination in grain sorghum. Agronomy Journal 53 (3): 187 188.

Taha, M. H. (1999). Chemical fertilizers and irrigation system in Egypt. 1999. Proceedings of the FAO Regional Workshop on Guidelines for Efficient Fertilizers Use through Irrigation. Cairo, 14-16 Dec. 98.

Tolk, J. A.; T. A. Howell; J. L. Steiner and D. R. Krieg (1995). Role of transpiration suppression by evaporation of intercepted water in improving irrigation efficiency. Irrigation Science 16: 89-95.

Wang, F.; Y. Kang and S. Liu (2006). Effects of drip irrigation frequency on soil wetting pattern and potato growth in North China Plain. Agricultural Water Manage. 79: 248-264.

Xu, G.; I. Levkovitch; S. Soriano; R. Wallach and A. Silber (2004). Integrated effect of irrigation frequency and phosphorus level on lettuce: P uptake, root growth and yield. Plant and Soil, 263(1-2): 297-309.

Yang, X.; F. Chen; F. Gong and D. Song (2000). Physiological and ecological characteristics of winter wheat under sprinkler irrigation condition. Trans. Chin. Soc. Agric. Eng. 16 (3): 35-37.

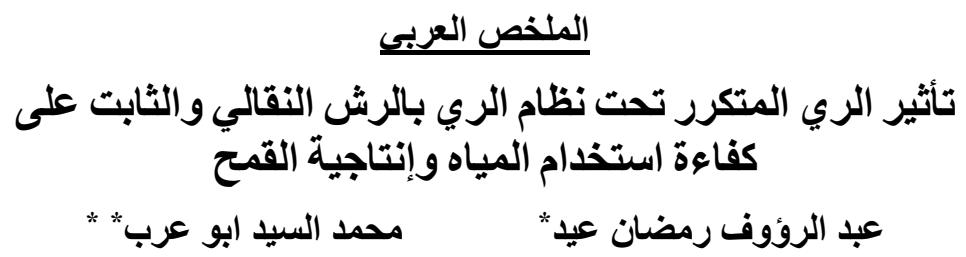

تم دراسة خصائص الأستهلاك المائي لمحصول القمح في منطقة النوبارية تحت نظام الري لإي

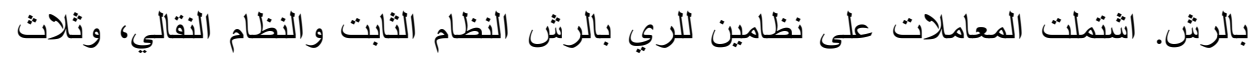

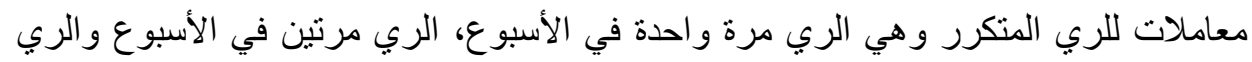

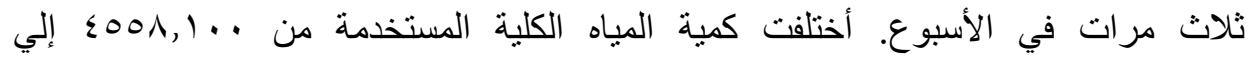
في

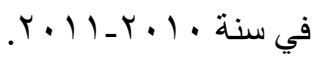

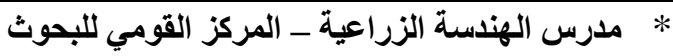
** مدرس الهندسة الزراعية ـ كلية الزراعة ـ جامعة القاهرة 
أعلى أستهلاك مائي تم الحصول عليه من النظام النقالي و الري ثلاث مر ات في الأسبوع في سنة

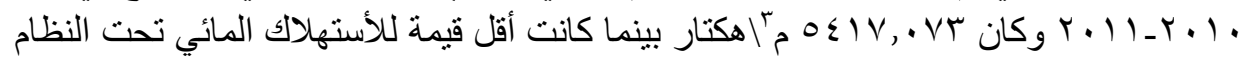

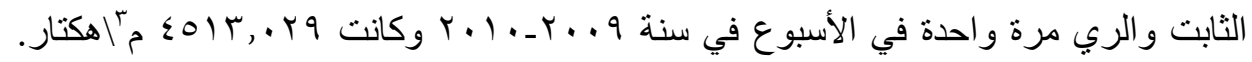

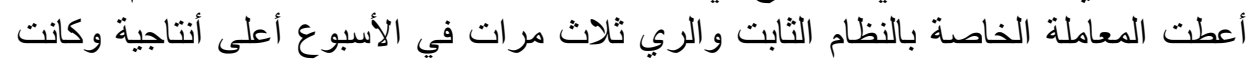

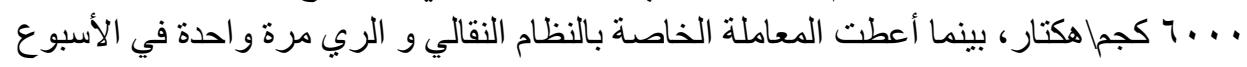

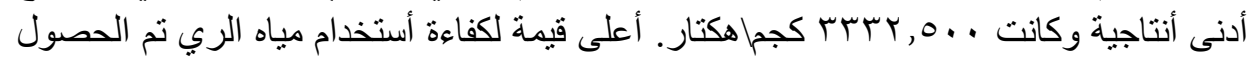

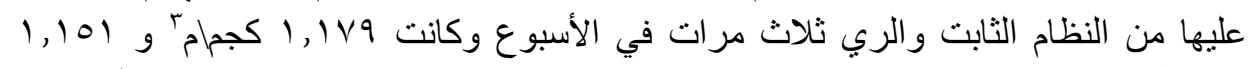

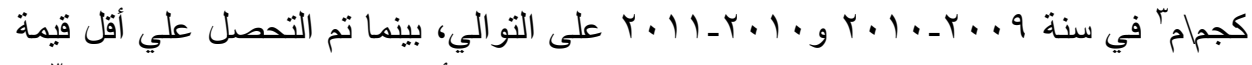

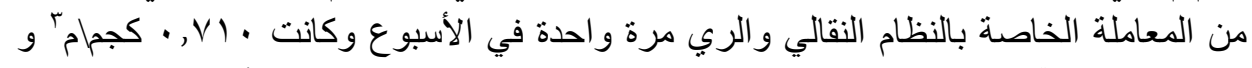

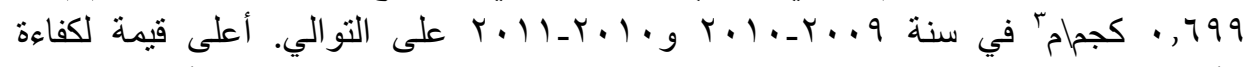

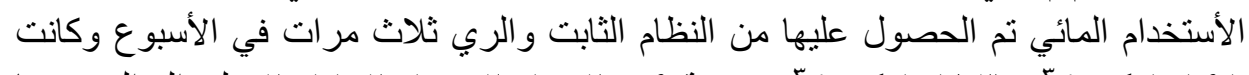

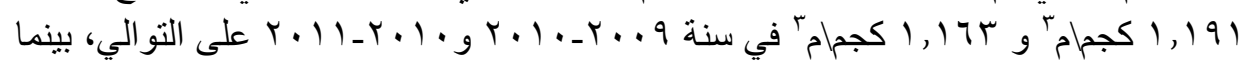

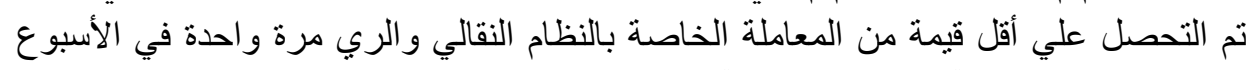

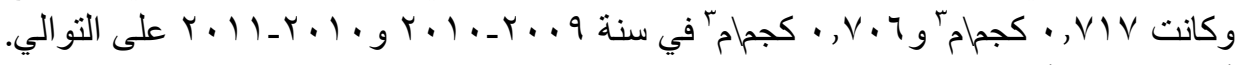

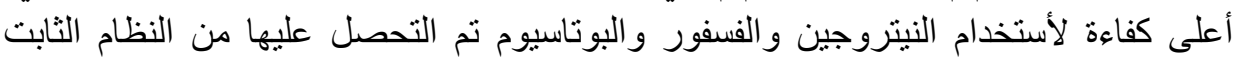

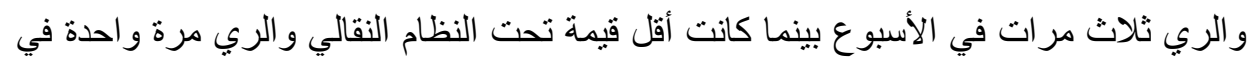

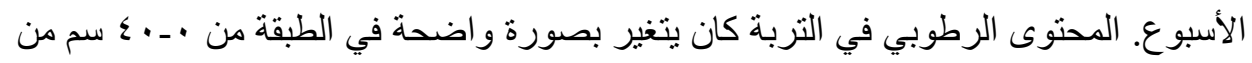

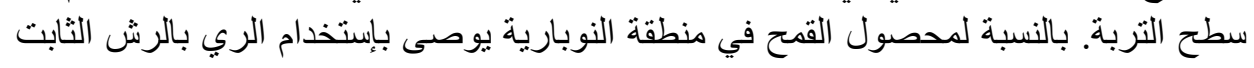
و الري ثلاث مر ات في الأسبوع. بأنس 